\title{
Size distribution of the jack Chloroscombrus chrysurus (Linnaeus) (Actinopterygii, Carangidae) in a tropical bay at Southeastern Brazil
}

\author{
Marcus R. da Costa ${ }^{1}$, Rafael J. Albieri ${ }^{1} \&$ Francisco G. Araújo ${ }^{1,2}$ \\ ${ }^{1}$ Laboratório de Ecologia de Peixes, Departamento de Biologia Animal, Instituto de Biologia, Universidade Federal Rural do \\ Rio de Janeiro. Antiga Rodovia Rio-São Paulo Km 47, 23851-970 Seropédica, Rio de Janeiro, Brasil.
}

2 Corresponding author. E-mail: gerson@ufrrj.br

\begin{abstract}
Chloroscombrus chrysurus (Linnaeus, 1766) is the most abundant representant of the Carangidae family in the Sepetiba bay, a c.a. $450 \mathrm{~km}^{2}$ semi-closed coastal area in the Southeastern Brazil. We analyze fish (number, weight and size) and environmental data to assess the part of life history of this species in tropical embayment environments. Fish sampling were taken in triplicates by monthly bottom trawls, in three bay zones (inner, middle and outer), defined according to a spatial gradient of depth and salinity. Juveniles were firstly caught in the inner bay zone measuring $30-90 \mathrm{~mm}$ total length $-\mathrm{TL}$ (mode $=60 \mathrm{~mm} \mathrm{TL}$ ) in Spring. Then they move toward the middle and outermost part of the bay in Summer-Autumn (120-180 mm TL), following a seaward migration to join the adults during the Winter. No early juveniles were recorded recruiting at sandy beaches of the Sepetiba bay, although spawning has been reported to take place at nearby coastal areas, with eggs and larvae penetrating into the innermost bay zones. At least two yearly classes coexist in the bay during the first two years. Environmental gradient of temperature, salinity, transparency, dissolved oxygen and depth are poor predictors of fish numbers and biomass, and the significant negative correlation with salinity and depth only reflect the large numbers of juveniles in the innermost part of the bay, where influence of continental drainage and sediment deposition is higher.
\end{abstract}

KEY WORDS. Coastal fishes, estuaries, growth, tropics.

RESUMO. Distribuição por tamanho da palombeta Chloroscombrus chrysurus (Linnaeus) (Actinopterygii, Carangidae) em uma baía tropical do sudeste do Brasil. Chloroscombrus chrysurus (Linnaeus, 1766) é o representante mais abundante da família de Carangidae na Baía de Sepetiba, uma área semi-fechada com $450 \mathrm{Km}^{2}$, localizada no sudeste do Brasil. Foram analisadas as CPUEs de número, peso e tamanho, além dos dados ambientais, a fim de avaliar parte do ciclo de vida desta espécie num ambiente de baía. As amostras foram realizadas mensalmente em triplicatas através de rede de arrasto de fundo, em três zonas da baía (interna, central e externa), definidas de acordo com um gradiente espacial de profundidade e salinidade. Juvenis foram registrados primeiramente na zona interna da baía, medindo entre $30-90 \mathrm{~mm}$ de comprimento total $-\mathrm{CT}$ (moda $=60 \mathrm{~mm}$ $\mathrm{CT})$ na primavera. Este mesmo grupo de tamanho desloca-se para as zonas central e externa da baía durante o verão-outono quando atingem $\mathrm{CT}=120-180 \mathrm{~mm}$, juntando-se posteriormente aos adultos no inverno. Jovens do ano não utilizam as praias arenosas da Baía de Sepetiba como área de recrutamento, embora a desova desta espécie ocorra na plataforma continental, com ovos e larvas penetrando em direção a parte mais interna da baía. Pelo menos duas classes anuais de tamanho coexistem na baía durante os primeiros dois anos. $\mathrm{O}$ gradiente ambiental de temperatura, salinidade, transparência, oxigênio dissolvido e profundidade foram pobres preditores para o número e o peso dos peixes, e a correlação negativa significante com salinidade e a profundidade reflete somente as altas abundâncias de jovens na parte mais interna da baía onde predominam maiores influências de drenagem continentais e maiores deposições de sedimento.

PALAVRAS CHAVE. Crescimento, estuários, peixes costeiros, trópico.

The Carangidae is one of the most diverse and abundant fish family in the world, occurring mainly in tropical waters, and almost all species are exploited to some degree (GUSHIKEN 1988). One of their species, known as jacks, Chloroscombrus chrysurus Linnaeus, 1766, shows a wide distribution along the shallow Brazilian tropical coastal waters, mainly in bays and estuarine areas; in the Western Atlantic there are records of this species from Massachusetts, USA, to Northern Argentina (Menezes \& Figueiredo 1980).

Revista Brasileira de Zoologia 22 (3): 580-586, setembro 2005 
Understanding fish distribution, mainly during early life stages, is important to evaluate recruitment, survival and growth rates. Relative abundance and distribution of different life cycle stages of $C$. chrysurus were reported by the Western Central Atlantic by JoHnson (1978) suggesting that adult distribution occurs from coastal waters to open ocean (up to $180 \mathrm{~m}$ depth). Flores-Coto \& Sanchez-Ramirez (1989) stated that larval stages (1.8-13.3 mm TL) were abundant at shallow waters $(<40$ $\mathrm{m}$ depth), near to estuaries and bays, along the Southeastern Mexico Gulf, and that high densities were recorded in coastal area near to Términos lagoon. Larvae stages were recorded in coastal water less than $30 \mathrm{~m}$ depth in the southeastern Brazilian Bight (Katsuragawa \& Matsuura 1992). Weiss et al. (1976) described the distribution and abundance of larvae along the Southern Brazilian coastal, reporting that juveniles occur up to $200 \mathrm{~m}$ depth. Despite the occurrence of eggs and larval forms to be relatively well documented, young-of-the-year and juvenile distribution are unknown yet. CunHA et al. (2000) found this species as a frequent part of the ichthyofauna in sandy beaches at Northeast Brazil, ranging from 30-170 mm TL, with early juveniles peaking in May-June.

In Sepetiba Bay, a sedimentary ca. $450 \mathrm{~km}^{2}$ embayment in the coast of Rio de Janeiro State at Southeastern Brazil, this species ranks among the most abundant fishes in experimental otter trawling ( $5^{\text {th }}$ place in numbers, occurring in $66.6 \%$ of the samples) (ARAújo et al. 2002). Furthermore, human impacts originate from outskirts of Rio de Janeiro City increase pollution in the Bay; it is estimated that the bay is receiving industrial outflows which corresponds potentially to $3,332 \mathrm{kd} \mathrm{d}^{-1}$ $\mathrm{DBO}_{5}$ and 48,694 $\mathrm{kg} \mathrm{d}^{-1}$ suspended solids (PFeIFFer et al. 1985).

Cycles of fish abundance in bays appear to be related to intrinsic biotic interactions and respond to variation in environmental conditions. This study aims to describe spatial and temporal distribution of C. chrysurus is Sepetiba Bay and to assess eventual environmental influences. We tested the hypothesis that they enter and leave the bay as part of their life cycle, since spawning has been reported to occur in nearby coastal areas (KatsuragaWa \& MatsuUra 1992).

\section{MATERIAL AND METHODS}

\section{Study area}

Sepetiba bay (Fig. 1) is located in the State of Rio de Janeiro, Southeast Brazil $\left(22^{\circ} 54^{\prime}-23^{\circ} 04^{\prime} S ; 43^{\circ} 34^{\prime}-44^{\circ} 10^{\prime} \mathrm{N}\right)$. Its connection with the sea is through a wide area at the west and a narrow channel at the east with a sandbank forming the southern limit and the continental margin at the north. Waters are predominantly polyhaline (salinity around 30) and the annual rainfall is between 1,000 and 2,100 mm (BARBIERI \& Kronemberger 1994) but this does not influence the bay salinity much due to the existence of only small tributaries. Most of the substrate is silt and mud. The tidal range is approximately $1 \mathrm{~m}$. Predominantly northeasterly and southwesterly winds activate thermal currents between the bay and the ocean.

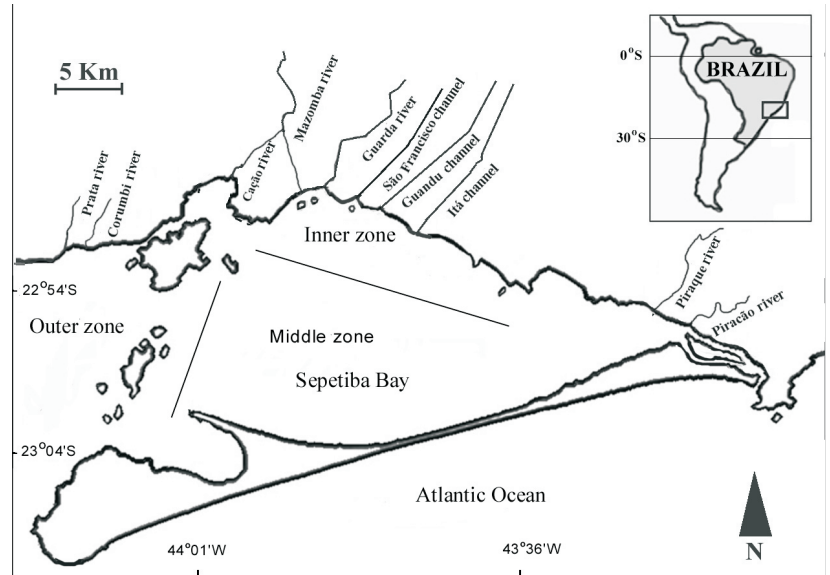

Figure 1. Study area, Sepetiba bay, with indication of the three bay zones (inner, middle and outer).

Sampling was taken monthly; between October 1998 and September 1999. We sampled nine sites, randomly chosen, covering the bay zones (inner, middle and outer), according to its proximity to the bay large connection to the ocean (three sites per zone). Inner zone shows lower salinity, transparency and depth and higher temperature, when compared to outer zone; middle zone showed intermediary values for this environmental variables (ArAújo et al. 2002).

\section{Data collection}

Fish were collected by 20 min duration bottom trawls, performed against the current, at a tow speed of approximately 2 knots, covering a distance of c.a.1,500 m, thus defining the unite effort. The trawl had a $8 \mathrm{~m}$ headline, $11 \mathrm{~m}$ ground rope 2.5 stretched mesh, and $1.2 \mathrm{~cm}$ mesh com-end liner. Following each trawl, hydrographic data were taken from bottom waters, collected by Van Dorn bottle, including temperature with $0.5^{\circ} \mathrm{C}$ precision and salinity with 0.5 precision. Dissolved oxygen was measured by a Horiba U-10 water quality meter. Transparency were recorded using a Secchi disk $(\mathrm{cm})$ and depth was determined with an echo-sounder. All caught fish were fixed in $10 \%$ formalin (diluted with the bay water) and after $48 \mathrm{~h}$ transferred to 70 ethanol. Identification was followed by measurements for total length - TL ( $\mathrm{mm})$ and weight $(\mathrm{g})$.

\section{Data analysis}

Fish and environmental data were standardized (centered and reduced) to fulfill homoscedasticity and normality requirements of parametric analyses, to eliminate effects of very abundant and rare species, and to balance the effects of different units of measurements of environmental parameters. Spatial (among zones) and. seasonal (among seasons) comparisons in both fish and environmental data were determined by analysis of variance (ANOVA). Relative fish abundance were assessed by both number and weight of fish by unit effort. An a poste- 
riori Tukey test $(\mathrm{p}<0.05)$ was used to determine differences in mean values following ANOVA (ZAR 1996).

Stepwise multiple regression was applied to fish and environmental data, with fish number and weight as dependent variables and environmental parameters as independents variables (predictors). Spearman rank coefficient were used to assess relationship between fish data relative abundance (number and weight) and environmental data.

Monthly length-frequency distributions were analyzed to assess indirect fish growth. Size classes were determined arbitrarily, considering the size range of fish population. The estimation of the growth parameters was based on size classes, by using the software FISAT GAYANILO \& PAULY (1997), routine ELEFAN I (Electronic Length Frequency Analysis). This routine estimates the parameters of the growth von Bertalanffy equation (PAUlY \& DAvid 1981), by defining $L \infty$ and $k$ values through the plan of growth curves, that represent cohorts on sequential samples. $L^{\infty}$ was estimated using the TAYLOR equation (1962), in which the asymptotic length was calculated by the following equation: $\mathrm{L}^{\infty}=\mathrm{L}_{\max } \times$ sampled/0.95. The growth performance index $(\phi)$ was calculated as follows: $\phi=\log (\mathrm{k})+2 \times \log \left(\mathrm{L}^{\infty}\right)($ Munro \& Pauly 1983).

\section{RESULTS}

\section{Spatial and temporal distribution}

The highest fish abundances (number and weight) were recorded in the inner zone followed by the middle zone (Fig. $2)$. Significant spatial difference $(p<0.05)$ was shown only for fish weight, with inner zone showing higher values than outer zone (Tab. I, Fig. 2). No seasonal difference was detected in fish abundance $(p>0.01)$ although a trend for higher values in Autumn and smaller in the winter was shown.

Table I. F-values (ANOVA) and Tukey differences in relative abundance for Chloroscombrus chrysurus per zones and seasons in Sepetiba bay, Brazil.

\begin{tabular}{|c|c|c|c|c|}
\hline & Zone $(Z)$ & Season $(S)$ & Interaction $(Z \times S)$ & Tukey \\
\hline Number & NS & NS & NS & - \\
\hline Weight & $6,37^{*}$ & NS & NS & $1>3$ \\
\hline
\end{tabular}

${ }^{*} p<0.01 ; N S=$ non-significant.

\section{Environmental influences on fish occurrence}

Significant higher salinity, transparency and depth and lower temperature were shown for outer zone compared to inner zone (Tab. II). Seasonally, highest values for temperature were recorded in Summer, for salinity in Spring-Summer, and for dissolved oxygen in Winter.

Negative Spearman correlation was shown between fish abundance (number and biomass) and salinity, transparency and depth, and positive with temperature (Tab. III). This pat-
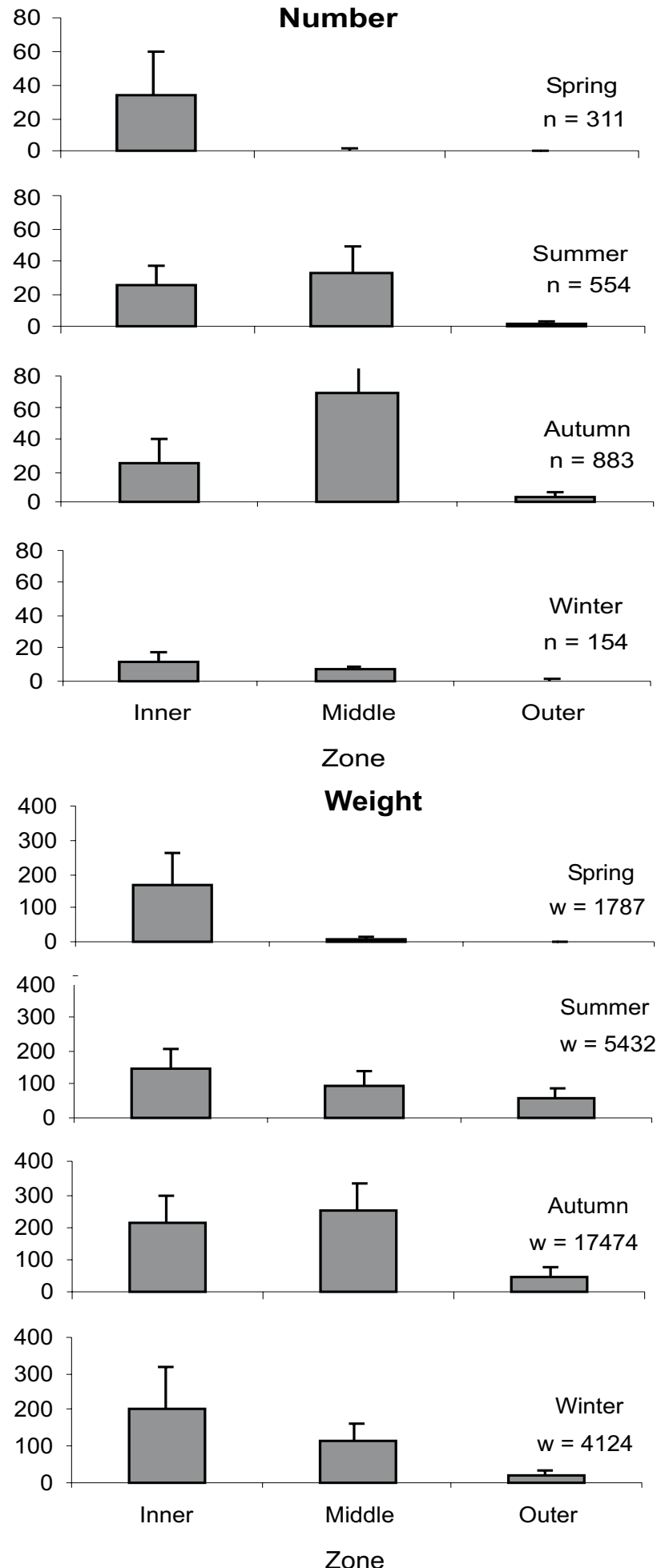

Figure 2. Spatial and seasonal distribution for relative abundance (number and weight) for Chloroscombrus chrysurus in Sepetiba bay, Brazil, 1998/99. 


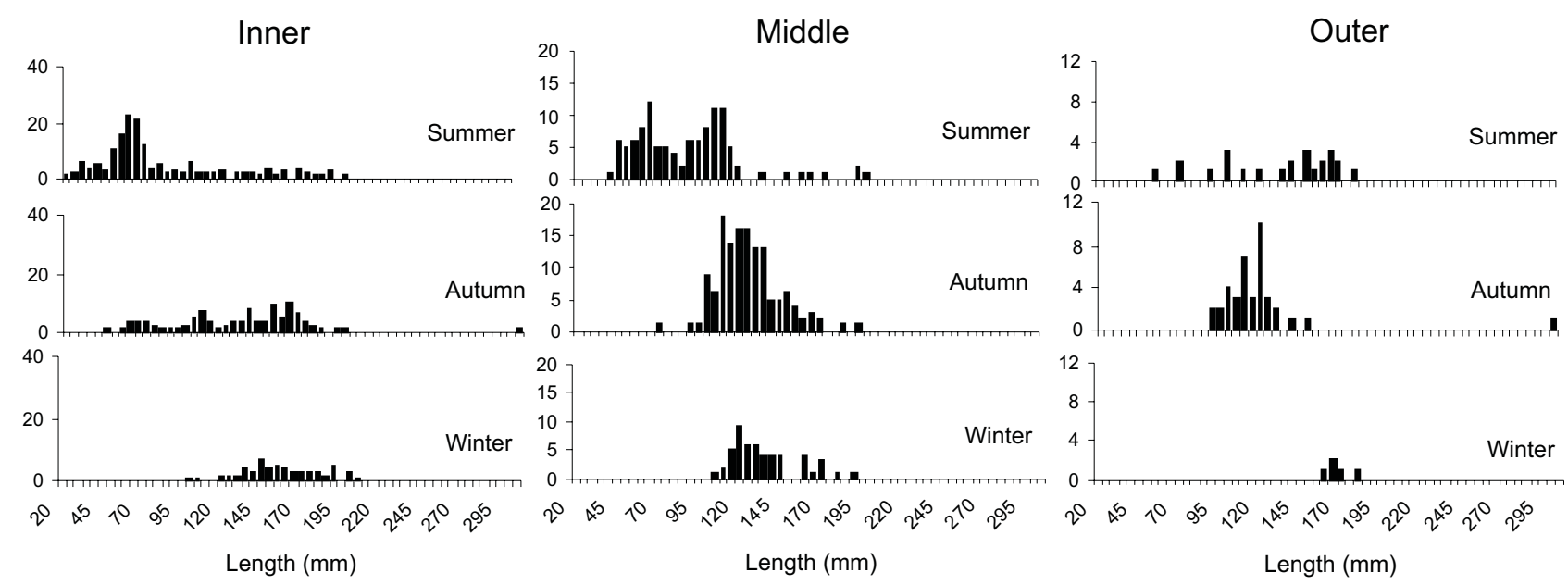

Figure 3. Seasonal length-frequency distribution of Chloroscombrus chrysurus by zones in the Sepetiba Bay, Brazil, 1998/99.

Table II. F-values (ANOVA) and Tukey comparisons for environmental variables among zones and seasons in the Sepetiba bay, Brazil. Zones: (i) inner, (m) middle, (o) outer; Seasons: (S) spring, (Su) summer, (A) autumn, (W) winter.

\begin{tabular}{lccccc}
\hline \multicolumn{1}{c}{ Environmental Variables } & Zone $(Z)$ & Season $(S)$ & Interaction $(Z \times S)$ & Tukey Zone & Tukey Season \\
\hline Temperature & $11.08^{* *}$ & $38.46^{* *}$ & $5.25^{* *}$ & $\mathrm{i}, \mathrm{m}>\mathrm{o}$ & $\mathrm{Su}>\mathrm{S}, \mathrm{A}, \mathrm{W}$ \\
Salinity & $43.02^{* *}$ & $10.74^{* *}$ & $\mathrm{NS}$ & $\mathrm{o}>\mathrm{m}>\mathrm{i}$ & $\mathrm{S}, \mathrm{Su}>\mathrm{A}, \mathrm{W}$ \\
Dissolved oxygen & $\mathrm{NS}$ & $3.43^{*}$ & $\mathrm{NS}$ & - & $\mathrm{W}>\mathrm{Su}$ \\
Transparency & $87.70^{* *}$ & $\mathrm{NS}$ & $\mathrm{NS}$ & $\mathrm{o}>\mathrm{m}>\mathrm{i}$ & - \\
Depth & $286.32^{* *}$ & $\mathrm{NS}$ & $\mathrm{NS}$ & $\mathrm{o}>\mathrm{m}>\mathrm{i}$ & - \\
\hline
\end{tabular}

${ }^{*} \mathrm{p}<0.05 ;{ }^{* *} \mathrm{p}<0.01 ; \mathrm{NS}=$ non-significant

Table III. Significant regression coefficient for Stepwise Multiple Regression Analysis and Spearman Ranks coefficient, between the number and weight of Chloroscombrus chrysurus and the studied environmental variables.

\begin{tabular}{|c|c|c|c|c|c|}
\hline Variables & Temperature & Salinity & Dissolved oxygen & Transparency & Depth \\
\hline \multicolumn{6}{|l|}{ Regression coefficient } \\
\hline Number & NS & NS & NS & NS & $-0.20^{*}$ \\
\hline Weight & NS & $-0.24 * *$ & NS & NS & NS \\
\hline \multicolumn{6}{|c|}{ Spearman rank coefficient } \\
\hline Number & $0.22^{*}$ & $-0.44^{* *}$ & NS & $-0.33^{* *}$ & $-0.40^{* *}$ \\
\hline Weight & NS & $-0.46^{* *}$ & NS & $-0.35^{\text {** }}$ & $-0.39 * *$ \\
\hline
\end{tabular}

tern reflects the higher fish abundance in the inner bay zone, with lower salinity, transparency and depth, and higher temperature. For dissolved oxygen there was no significant correlation. On the other stepwise multiple regression showed significant negative relationship between depth and numbers of individuals $(p<0,05)$ and salinity and weight $(p<0,01)$ only. Therefore, only these two latter relationships were consistent, since they were detected by both, Spearman correlation and stepwise multiple regression coefficients (Tab. III).

\section{Size distribution}

A total of 1902 individuals were caught in the 108 bottom trawling samples. Individuals size ranged from 20 to $300 \mathrm{~mm}$ TL. Seasonal length-frequency distribution showed that individuals with smaller size (30-90 mm TL) appeared firstly in Spring and Summer at the inner zone (mode $=70 \mathrm{~mm} \mathrm{TL}$ ). Most of individuals move to the middle bay zone in Summer (70-145 mm TL) and Autumn (100-180 mm TL); during the Winter, only a few individuals are recorded in the Bay, ranging 


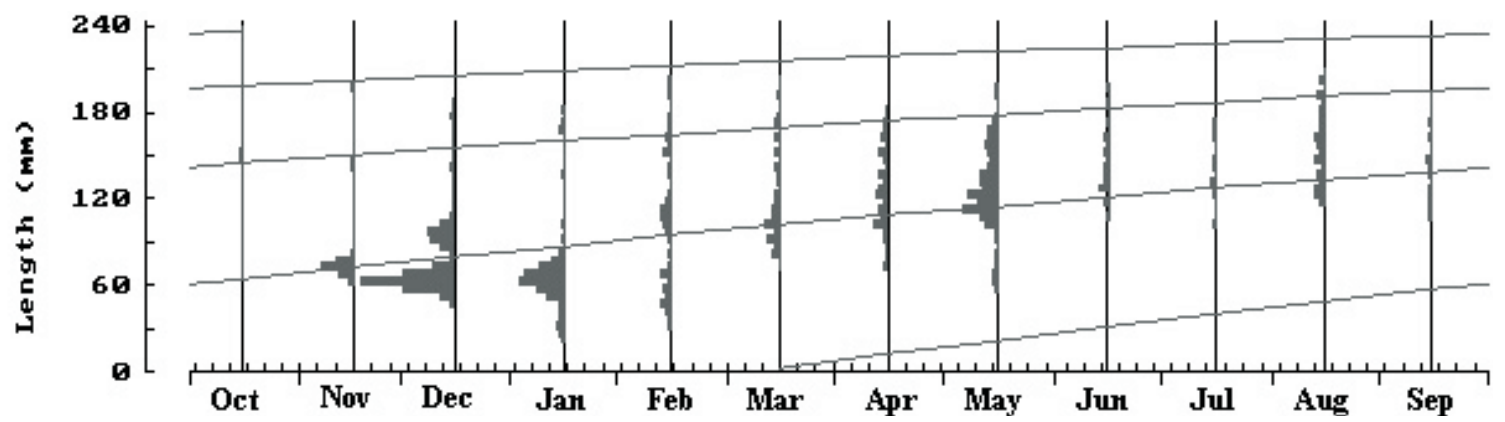

Figure 4. Modal monthly progression with respective cohorts, from FISAT sub-routine ELEFAN I, for Chloroscombrus chrysurus, between October 1998 ad September 1999.

from 120-200 mm TL in the inner and middle zones, and 170$200 \mathrm{~mm}$ TL in the outer zone. Following the length-frequency modes, we can assess fish growth, with smaller group size increasing from 30-70 mm TL in spring, reaching approximately 130-150 mm TL in Winter (Fig. 4).

Fish structure was comprised by smaller sized fish (mode $=70 \mathrm{~mm} \mathrm{TL}$ ) in the highest numbers, and two additional few represented size groups showing modes of approximately 95 and $150 \mathrm{~mm}$ TL, basically in Summer and Autumn in the inner and middle zone. The outer zone showed much lower number of individuals not presenting a conspicuous mode (Fig. 4).

\section{Growth parameters}

The maximum asymptotic value $(\mathrm{L} \infty)$ of $316 \mathrm{~mm}$ was found according to TAYLOR's equation. The growth parameters estimated by ELEFAN I routine and the performance index $(\phi)$ which presented the best adjustment, considering non-oscillatory growth $(\mathrm{C}=0$ and $\mathrm{WP}=0)$ were as follow: $\mathrm{k}=0.38$ year $^{-1}$ and $\phi=2.58$. Four curves were adjusted by the model, representing four cohorts, starting in April, where no fish was recorded. Only in November the smaller sized group appeared (mode $=60 \mathrm{~mm} \mathrm{TL})$, reaching in March, at the end of the first year $120 \mathrm{~mm}$ TL. Two other size groups were determined by the model reaching approximately $150 \mathrm{~mm}$ and $190 \mathrm{~mm}$ TL at the end of the second and third year. An acceptable adjust in$\operatorname{dex}(\mathrm{Rn}=0.124)$ was found (Fig. 5).

\section{DISCUSSION}

Chloroscombrus chrysurus uses the innermost part of the Sepetiba Bay during early life cycle, with young-of-the-year and juveniles appearing in Spring-Summer, and remaining in the area in high abundances during the Autumn. Afterwards, they are scarcely recorded, probably migrating to adjacent coastal areas, or to other areas of the Bay where the fish equipments were not used. These high numbers in the Bay match with the founds by SHaw \& Drullinger (1990), Graça Lopes et al. (1993) and CunHa et al. (2000) that pinpoint this species as an important part of the fish assemblages in bays and estuaries.

Eggs and larval forms are brought by currents from spawn- ing areas in the adjacent coast, penetrating into the bay by its west bound, and reaching the innermost bay areas, where they use as rearing grounds. KatsuragaWa \& MatsuURA (1992) reported eggs along the Southeast Brazil continental shelf. FLORES-Сото \& SANCHEZ-RAmirez (1989) also found eggs and larval forms between 15 and $40 \mathrm{~m}$ depth in México Gulf. Therefore, it is reasonable to assume that this species use the continental shelf to spawn and the more protected embayment areas as rearing grounds. The use of bays and estuarine areas during early life cycle might be associated with food and other resources availability and microhabitat diversity of such environments. BLABER \& Blaber (1980) and PETERSON $\&$ WHIFIELD (2000) reported that the highly product ivy calm and shallow vegetated waters comprise favourable conditions to juveniles development by supplying food and protection.

The inner Sepetiba bay zone, where influences from continental drainage are more noticeable, as well are the anthropogenic influences from urban-industrial plants at outskirt of Rio de Janeiro City, are associated with water of higher temperature and lower transparency, salinity and depth. Relationship between these environmental variables and fish abundance were not consistent, except for the significant inverse association between numbers of individuals $v s$. depth, and biomass vs. salinity, but this is more likely to reflect the inner area conditions then a dependence relationship. Furthermore, the higher stress condition of the inner zone Pfeifer et. al. (1985) is not likely to be a limiting constraint for fish distribution during early life stages. NiкоLsKy (1969) reported that fish species can copy with continuously dynamic environmental conditions and that population structure may be shifted within the species limit, with this tactic flexibility representing degrees of adjustment to optimise survival in stress conditions. Therefore, higher abundances recorded in the inner Bay, reflect the present and past environmental conditions in which this fish populations developed, and it is assumed that $C$. chrysurus show high capacity to undergo to changeable environmental conditions.

Another aspect that could be contributing to higher fish abundance in the inner bay zone are the organic loads brought into the bay by municipal effluent discharges (Pfeiffer et al. 1985), increasing primary productivity and other compartment 
of the trophic web, including fishes and small crustaceans (CuNHA et al. 2000). This pattern of high abundance in the inner zone for the more tolerant species was detected for the Sepetiba bay by Araújo et al. (1998, 2002). Muto et al. (2000) recorded C. chrysurus occurrence along the São Sebastião, São Paulo, continental shelf, while CunHA et al. (2000) also recorded this species in bottom trawling in the Northern Brazil continental shelf.

Recruits in the first days of life were not recorded in bottom trawls, although it is believed to use some part of the bay, since only when they reach 30-90 $\mathrm{mm}$ TL they start to be record in the Spring. Where is the area used by post-larvae and early juveniles in this meantime is still a question. This species do not occur in sandy beach at the inner bay, where the closely related Sciaenidae, Gerreidae, Engraulidae and Mugilidae recruit in large number (12-30 mm TL), according to several previous observations (Pessanha et al. 2003, DA Costa \& ARAujo 2003).

Juvenile fish can use floating structures, such as jellyfish, during part of life cycle, where they found protection from predators, but to which they sometimes fall prey (DEMPSTER 2005). The fish-jellyfish association is regarded as a temporary symbiosis. Young fishes associated with jellyfish tend to stay over the umbrella of the medusa and come down in direction of the tentacles only while frightened or while feeding on the medusa itself, as reported by BonALDo et al. (2004) that found Trachurus lathami Nichols, 1920 (Carangidae) associated with the jellyfish Chrysaora lactea Eschscholtz, 1829 (Pelagiidae). Tolley (1987) found young-of-the-year C. chrysurus in symbiotic association with medusa in the Tampa Florida Bay, mainly during the lowest size classes $(0.5-20 \mathrm{~mm}$ TL). Several studies carried out in the Sepetiba Bay sandy beaches (ARAújo et al. 1997, Pessanha et al. 2000, 2003) showed that this species is rather scarce, confirming that they do not recruit at these areas. DA Costa (pers. comm.) observed high number Scyphozoa (Celenterate) all over the bay during the Summer, coinciding with the increased number of smaller individuals, and suggest that $C$. chryrsurus could be using the same strategy described by Tolley (1987) during early life.

Overall, juveniles arrive at the inner Bay area in Late Spring/Summer (20 mm TL), remaining in the area during Autumn, with the largest size reaching $220 \mathrm{~mm}$ TL. In Winter they move to deeper areas in the middle and outer zones, as they grown and search for new food resources. This matches with JoHnson (1978) that reported this species explore deeper areas (up to $1800 \mathrm{~m}$ ) as they grown, in the middle Atlantic Bight.

Size structure in the Sepetiba Bay ranged from 20-300 $\mathrm{mm}$ TL being higher to those reported by other environments. Magro et al. (2000) and CunHa et al. (2000) observed a narrow range for Southeastern-South (100-220 mm TL) and Northeast (30-170 mm TL) Brazil, respectively. This suggests more suitable conditions in the inner Sepetiba Bay compared with those environments. Wider size classes indicates several size group coexisting in space and time and usually are related with favourable habitat to fish development.
Indications of three size groups can be observed by examining length-frequency distribution, the first (50-70 mm TL) evidencing the juveniles recruiting, the second (100-130 mm TL) representing individuals more than one-year old, and the lesser evident third group, representing different larger size less (150$170 \mathrm{~mm} \mathrm{TL}$ ). The smallest fishes peak firstly at the inner zone in Spring/Summer, then move to the central and outer zone when they reach larger sizes in Autumn/Winter. This third size group comprises adults species, since the length at first spawning at Southeastern Brazil is $115 \mathrm{~mm}$ TL (MAGro et al. 2000). At lower latitudes, such as in Northeast Brazil, this species reaches length at first spawning at $95 \mathrm{~mm}$ TL CUNHA et al. (2000). Although it is difficult to compare different areas where differentiated fish effort were used, the presence of species in different size indicate the wide distribution of this species which has great plasticity to explore different habitats enabling the success along its evolutionary development. The patterns founds for C. chrysurus in the present work departure somehow from the majority of abundant species that recruit in sandy bay beaches, but this species use the inner bay zones as part of their life cycle, since spawning has been reported to occur in nearby coastal areas.

\section{CONCLUSIONS}

Chloroscombrus chrysurus uses the innermost zone of the Sepetiba Bay as rearing grounds, with eggs and larval forms penetrating in the bay from the adjacent coastal area.

Young-of-the-year recruitment occurs in Spring/Summer, with high abundance in Autumn. Then, the moved away to deeper areas in Winter.

The lowest salinity and depth at the inner and central Sepetiba Bay zones were associated with the highest fish abundance, although no significant dependence relationship was detected between fish occurrence and environmental variables. Furthermore, the more stress condition of the inner Sepetiba Bay do not limit fish occurrence in the area.

At least three size groups coexist in the Sepetiba Bay, with recruits growing from $60 \mathrm{~mm}$ TL in November to $120 \mathrm{~mm}$ TL in March, at the end of the first year.

\section{ACKNOWLEDGMENTS}

We thank Francisco José da Costa Guimarães, Leonardo Mitrano Neves, André Luiz Balbino dos Santos e Hamilton Hissa Pereira for helping in fieldwork. This work was financially supported by $\mathrm{CNPq}$ - Brazilian National Agency for Scientific and Technological Development (Proc. 522317/96-0) and Rio de Janeiro Agency for Research Development (Proc. E-26/170.258/2001).

\section{REFERENCES}

Araújo, F.G.; A.G. Cruz-Filho; M.C.C. Azevedo \& A.C.A. Santos. 1998. Estrutura da comunidade de peixes demersais da Baía de Sepetiba. Revista Brasileira de Biologia, São Carlos, 58 (3): 417-430. 
Araúuo, F.G.; A.G. Cruz-Filho; M.C.C. Azevedo; A.C.A. Santos \& L.A.M. FernANDEs. 1997. Estrutura da comunidade de peixes jovens da margem continental da Baía de Sepetiba, RJ. Acta Biologica Leopoldensia, São Leopoldo, 19 (1): 61-83.

Araújo, F.G.; M.C.C. Azevedo; M.A. Silva; A.L.M. Pessanha; I.D. Gomes \& A.G. Cruz-Filho. 2002. Environmental influences on the demersal fish assemblages in the Sepetiba Bay, Brazil. Estuaries, Kansas, 25 (3): 441-450.

Barbieri, E.B. \& D.M. Kronemberg. 1994. Climatologia do litoral Sul-Sudeste do estado do Rio de Janeiro: Um subsídio ä análise ambiental. Caderno de geociências, Rio de Janeiro, 12: 57-73.

Blaber, S.J.M. \& T.G. Blaber. 1980. Factores affecting the distribution of juvenile estuarine and inshore fish. Journal of Fish Biology, Drumfries, 17: 143-162.

Bonaldo, R.M.; J.P. Krajewski \& I. Sazima. 2004. Does the association of young fishes with jellyfishes protetc from predation? A report on a failure case due to damage to the jellyfish. Neotropical Ichthyology, Porto Alegre, 2 (2): 103-105.

Cunha, F.E.A.; J.E.P. Freitas; C.V. Fitosa \& C. Monteiro-Neto. 2000. Biologia e biometria da palombeta, Chloroscombrus chrysurus (Linnaeus, 1766) (Teleostei: Carangidae), em fortaleza, Ceará, Brasil. Arquivos de Ciência do Mar, Fortaleza, 33: 143148.

da Costa, M.R. \& F.G. Araújo 2003. Use of tropical bay in southeastern Brazil by juvenile and subadult Micropogonias furnieri (Perciformes, Sciaenidae). ICES Journal of Marine Science, United Kingdom, 60: 268-277.

Dempster, T. 2005. Temporal variability of pelagic fish assemblages around fish aggregation devices: biological and physical influences. Journal of Fish biology, Drumfries, 66: 1237-1260.

Flores-Coto, C. \& M. Sanchez-Ramirez. 1989. Larval distribution and abundance of Carangidae (Pisces), from the Southern Gulf of Mexico. Gulf Research Report, México, 8 (2): 117 128.

Gayanilo JR., F.C. \& D. Pauly. 1997. FAO-ICLARM Stock Assessment Tools (FISAT). Reference manual. FAO computerized information series (Fisheries), Rome, 8 (2): 1-249.

Graça Lopes, R. da; E. Severino-Rodrigues; A. Puzzi; J.B. Pita; J.A.P.Coelho \& M.L. DE Freitas. 1993. Levantamento ictiofaunistico em um ponto fixo na Baía de Santos, Estado de São Paulo, Brasil. Boletim Instituto de Pesca, São Paulo, 20: 7-20.

Gushiken, S. 1988. Phylogenetic relationships of the Perciform genera of the family Carangidae. Japan Journal Ichthyology, Tokyo, 34: 443-461.

Johnson, G.D. 1978. Development of the fishes of the midAtlantic Bight. An atlas of egg, larval and juvenile stages. Boston, U.S. Fish Wildlife Service Program, FWS/OBS, vol. 4, 314p.

Katsuragawa, M. \& Y. Matsuura. 1992. Distribution and abundance of carangid larvae the southeastern Brazilian bight during 1975-1981. Boletim Instituto Oceanográfico, São Paulo,
$40(1 / 2): 55-78$.

Magro, M.; M.C. Cergole \& C.L.D.B. Rossi-Wongtschowski. 2000. Síntese de conhecimentos dos principais recursos pesqueiros costeiros potencialmente explotáveis na costa Sudeste-Sul do Brasil: peixes. São Paulo, REVIZEE, 145p.

Menezes, N.A. \& J.L.Figueiredo. 1980. Manual de Peixes Marinhos do Sudeste do Brasil IV. Teleostei (3). São Paulo, Museu de Zoologia, 96p.

Munro, J.L. \& D. Pauly 1983. A simple method for comparing the growth of fishes and invertebrates. Fishbyte, Manila, 1 (1): 5-6.

Muto, E.Y.; L.S H. SoARES \& C.L.D.B. Rossi-WongTSChOWSKI. 2000. Length-weight relationship of marine fish species off São Sebastião system, São Paulo, southeastern Brazil. Naga the ICLARM quarterly, Makati City, 23 (4): 27-29.

Nikolsky, G.V. 1969. Theory of fish population dynamics. Edinburg, Oliver \& Boyd, I+323p.

PAuly, D. \& N. DAvid. 1981. ELEFAN I, a BASIC program for the objective extraction of growth parameters from length frequency data. Report Marine Research, Meeresforsch, 28 (4): 205-211.

Pessanha, A.L.M.; F.G. Araujo; M.C.C. Azevedo \& I.D. Gomes. 2000. Variações temporais e espaciais da comunidade de peixes jovens da Baía de Sepetiba, RJ. Revista Brasileira de Zoologia, Curitiba, 17 (1): 251-261.

Pessanha, A.L.M.; F.G.Araujo; M.C.C. Azevedo \& I.D. Gomes. 2003. Diel and seasonal changes in the distribution of fish on a southeast Brazil sandy beach. Marine biology, Berlin, 143: 1047-1055.

Peterson, A.W. \& A.K. Whitfield. 2000. Do shallow water habitats function as refugia for juvenile fishes? Estuarine, Coastal and Shelf Science, Amsterdam, 51: 359-364.

Pfeiffer, W.C.; L.D. Lacerda; M. Fiszman \& R.W. Lima. 1985. Heavy metal in fishes from Sepetiba Bay, Rio de Janeiro State. Ciência e Cultura, Campinas, 37: 297-302.

Shaw, F.R. \& D.L. Drullinger. 1990. Early Life history profiles, seasonal abundance and distribution of four species of Carangidae larvae off Louisiana, 1982 and 1983. NOAA Techniques Report, Seattle, 89: 1-37.

TAYlor, C.C. 1962. Growth equations with metabolic parameters. Journal Council Intenational for the Exploration of the Sea, Copenhagen, 27 (3): 270-286.

Tolley, S.G. 1987. Association of young Chloroscombrus chrysurus (Pisces: Carangidae) with the jellyfish Aurelia aurita. Copeia, Kansas, (1): 216-219.

Weiss, G.; J.A.Feijo Souza \& A. Santos. 1976. Contribution to the knowledge of the marine ichthyoplankton on the southern shelf of Brazil. Atlântica, Rio Grande, 1 (1/2): 79-99.

ZAR, J.H. 1996. Biostatistical Analysis. Englewoods Cliffs, Prentice Hall, $3^{\text {rd }}$ ed., 662p.

Received in 14.X.2004; accepted in 22.VII.2005. 